\title{
PERBEDAAN KEKERASAN PERMUKAAN ENAMEL SETELAH APLIKASI FLUORIDE VARNISH DAN CASEIN PHOSPO PEPTIDE-AMORPHOUS CALSIUM PHOSPHATE FLUORIDE (CPP-ACPF) (PENELITIAN IN VITRO)
}

Differences Of Enamel Surface Hardness After Application Of Fluoride Varnish And Casein Peptide-Amorphous Calcium Phosphate Fluoride (CPP-ACPF) (In Vitro)

\section{Sinta Puspita*, Adioro Soetojo**, Sri Kunarti**}

\begin{abstract}
Background: Caries is a chronic, slowly progressing disease, with symptoms not detected at the onset of the disease but generally much later. Its initiation is associated with demineralization (calcium and phosphate loss) of subsurface tooth enamel, resulting in the formation of a subsurface lesion. To restore the natural equilibrium, either remineralization must be enhanced or demineralization must be retarded. There are some topical agents that can enhance remineralization such as topical fluor and casein phosphopeptide - amorphous calcium phosphate (CPPACP). Purpose: The aim of this study is to analyze the differences of the enamel surface microhardness after application of fluoride varnish and CPP-ACPF. Methode: 27 blocks bovine enamel were devided into 3 groups. Group 1 -control (No surface treatment), group 2 - fluoride varnish and group $3-C P P-A C P F$. Initial surface hardness enamel was measured for all enamel specimens. Artificial enamel carious lesions were created by immersing enamel samples to demineralization solution $\left(\mathrm{pH} \mathrm{4,5)}\right.$ for 72 hours at temperature $37^{\circ} \mathrm{C}$. The surface microhardness of demineralized enamel specimens was measured. A caries progression test ( $\mathrm{pH}$ cycling) was carried out, which consisted of alternative demineralization (3 hours), remineralization with artificial saliva (21 hours) and application topical agent twice a day for 14 days. Then, the last surface enamel microhardness is measured. Result: Group 3 showed significantly highest Vickers hardness number $(P<0,05)$ followed by group 2 and the lowest is group 1. Conclusions: This study proved that enamel surface microhardness after application of CPP-ACPF was higher than fluoride varnish.
\end{abstract}

Keywords : CPP-ACP, fluoride varnish, Remineralization, Demineralization

\section{PENDAHULUAN}

Karies merupakan penyakit kronis, berkembang perlahan-lahan, dengan gejala tidak terdeteksi diawal. Dalam lingkungan yang netral, hidroksiapatit dari enamel berada dalam keseimbangan dengan saliva yang jenuh dengan ion kalsium dan fosfat. Pada $\mathrm{pH} \leq 5,5$ terjadi pelarutan enamel yang disebut sebagai demineralisasi yang menjadi tanda dari awal karies enamel. Namun, demineralisasi dapat diubah menjadi remineralisasi jika $\mathrm{pH}$ dinetralkan dan ada ion kalsium dan fosfat yang cukup tersedia di lingkungan terdekat. Hal ini memungkinkan pembangunan kembali kristal apatit sebagian yang telah dilarutkan yang biasa disebut sebagai remineralisasi. Untuk mengembalikan keseimbangan alaminya, remineralisasi harus ditingkatkan dan atau demineralisasi harus dihambat. ${ }^{1}$

Fluor adalah bahan yang paling umum digunakan untuk "pemulihan" dari proses awal karies. Kehadiran fluor dalam saliva dan plak selama 
proses kariogenik dapat menghambat pelarutan kristal enamel dan meningkatkan remineralisasi. Penambahan aplikasi fluor sangat dianjurkan. $^{2}$ Pembentukan kristal fluorhidroksiapatit akan mengurangi demineralisasi enamel dan meningkatkan remineralisasi. Deposisi yang pesat dari fluorapatit membentuk lapisan permukaan yang keras yang lebih resisten terhadap demineralisasi. ${ }^{1}$

Dalam beberapa tahun terakhir, casein phosphopeptide-amorphous calcium phosphate (CPP-ACP) nanokompleks telah menunjukkan sifat antikariogenik baik pada hewan laboratorium maupun manusia dalam percobaan in situ. CPP dapat menstabilkan kalsium fosfat dalam larutan kalsium fosfat amorf (ACP) dan telah terbukti secara in vitro terlokalisir pada permukaan gigi, mencegah demineralisasi dan membantu dalam remineralisasi. ${ }^{3}$ CPP juga menstabilkan amorphous calcium MATERI DAN METODE

Jenis penelitian eksperimental laboratoris.

\section{Alat dan Bahan Penelitian}

Alat :

1. Glass tube

2. Karburudum disc

3. Spatula semen

4. dappen glass

5. bowl

6. Spatula besar

7. Lieca Japan, Tokyo, Vickers micro hardness tester

Bahan :

1. Fluoride varnish (fluorprotector intro pack; Ivaclar Vivadent)

2. Amorphous calcium phosphate - Casein phosphopeptide (CPP-ACP) dengan fluor GC Tooth Mousse Plus, Recaldent; GC Corp; Japan

3. Larutan demineralisasi yang terdiri dari :

1. $2,2 \mathrm{mM} \mathrm{CaCl}_{2}$ fluoride phosphate (ACPF) yang memiliki efek remineralisasi lebih baik pada lesi karies dibandingkan dengan fluor ataupun CPP-ACP secara individu. Penelitian ElSayad et al. membuktikan adanya efek yang sinergis dari gabungan fluor dan CPPACP dalam remineraliasi pada erosi enamel. ${ }^{4}$

Bahan fluoride varnish dan bahan kombinasi fluor dan CPP-ACP telah terbukti dapat meningkatkan remineralisasi pada gigi setelah aplikasi selama 7 hari namun menurut Lata et al. tidak ada perbedaan signifikan antara kedua kelompok tersebut. Oleh karena itu penulis ingin membandingkan kedua bahan tersebut dalam meningkatkan remineralisasi enamel gigi dengan waktu yang lebih lama yaitu 14 hari. Remineralisasi enamel dalam penelitian ini dilihat berdasarkan kekerasan permukaan enamel. $^{1}$

2. $2,2 \mathrm{mM} \mathrm{NaH}_{2} \mathrm{PO}_{4}$

3. $0,05 \mathrm{M}$ Lactic Acid

4. $0,2 \mathrm{ppm}$ fluor

Larutan tersebut diatur sedemikian rupa menggunakan $50 \% \quad \mathrm{NaOH}$ agar $\mathrm{pH} 4,5$

4. Larutan saliva buatan yang terdiri dari $:^{1}$

1. $3,9 \mathrm{mM} \mathrm{Na}_{3} \mathrm{PO}_{4}$

2. $4,29 \mathrm{mM} \mathrm{NaCl}_{2}$

3. $17,98 \mathrm{mM} \mathrm{KCl}$

4. $1,1 \mathrm{mM} \mathrm{CaCl}_{2}$

5. $0,08 \mathrm{mM} \mathrm{MgCl}_{2}$

6. $0,5 \mathrm{mM} \mathrm{H}_{2} \mathrm{SO}_{4}$

7. $3,27 \mathrm{mM} \mathrm{NaHCO}_{3}$

8. Air matang dan $\mathrm{pH}$ diatur pada level 7,2

\section{Prosedur Penelitian}

Sampel menggunakan 27 elemen gigi insisif rahang bawah sapi dalam keadaan utuh, tidak ada retakan 
dan tidak ada karies. Bagian fasial mahkota gigi dipotong dengan ukuran $4 \mathrm{~mm} \times 4 \mathrm{~mm} \times 2 \mathrm{~mm}$ menggunakan karburudum disc. Potongan enamel diletakkan di tengah Resin akrilik self cured berukuran $20 \mathrm{~mm} \times 10 \mathrm{~mm} \times 5$ $\mathrm{mm}$. Potongan enamel dihaluskan dengan silicon carbide paper dengan ukuran 500-grit dan diakhiri dengan ukuran 5000-grit dibawah air dingin sampai permukaan rata. Dilakukan tes microhardness awal pada semua sampel dengan beban 500 gram (Initial Enamel). Semua subyek gigi dibagi menjadi 4 :

Kelompok 1 : sebagai kontrol, tidak diaplikasikan bahan apapun

Kelompok 2 : sampel enamel yang telah disiapkan diaplikasikan 10,5 mg fluoride varnish menggunakan brush applicator, biarkan meresap selama 1 menit (sesuai petunjuk pabrik)

Kelompok 3 : sampel enamel yang telah disiapkan diaplikasikan 15,9 $\mathrm{mg}$ krim CPP-ACPF menggunakan brush applicator, diamkan selama 3 menit (sesuai petunjuk pabrik)

Pembuatan lesi awal pada sampel :

1. Rendam semua sampel pada glass tube yang berisi $20 \mathrm{ml}$ larutan demineralisasi selama 72 jam dalam ruang incubator dengan suhu 37 derajat. $^{1}$

2. Dilakukan evaluasi perhitungan surface microhardness dengan beban $500 \quad$ gram (Demineralized Enamel)

Tahap pH cycling : ${ }^{1}$

1. Masing-masing sampel diberi perlakuan berbeda sesuai kelompoknya. Aplikasi bahan dilakukan $2 \mathrm{x}$ sehari.

2. Setiap harinya sampel mengalami demineralisasi dengan dimasukkan sampel pada larutan demineralisasi selama 3 jam dan mengalami fase remineralisasi dengan direndam pada larutan saliva buatan selama 21 jam.
3. $\mathrm{pH}$ cycling berlangsung selama 14 hari.

4. Setelah $\mathrm{pH}$ cycling selesai dilakukan uji surface microhardness dengan beban 500 gram (Treated Enamel).

Penentuan presentase pemulihan surface microhardness dengan rumus :

$$
\frac{\mathrm{TE}-\mathrm{DE}}{\mathrm{IE}-\mathrm{DE}} \times 100 \%
$$

Keterangan :

TE : Treated Enamel

DE : Demineralized Enamel

IE : Initial Enamel

\section{HASIL}

Terdapat 3 kelompok dan tiap sampel pada masing-masing kelompok dilakukan 3 kali pengukuran kekerasan permukaan enamel. Hasil rerata kekerasan permukaan dan standar deviasi ditampilkan pada tabel 1 .

Tabel 1. Hasil Rerata Dan Standar

Deviasi Surface Microhardness

Enamel Setelah Aplikasi CPP-ACPF dan Fluoride Varnish (HVN)

\begin{tabular}{|c|c|c|c|c|c|c|c|}
\hline \multirow{2}{*}{$\begin{array}{l}\text { Kelo } \\
\text { mpo } \\
\text { k }\end{array}$} & \multicolumn{2}{|c|}{$\begin{array}{c}\text { HVN } \\
\text { IE }\end{array}$} & \multicolumn{2}{c|}{$\begin{array}{c}\text { HVN } \\
\text { DE }\end{array}$} & \multicolumn{2}{c|}{$\begin{array}{c}\text { HVN } \\
\text { TE }\end{array}$} & \multirow{n}{n}{} \\
\cline { 2 - 7 } & $\begin{array}{c}\text { Me } \\
\text { an }\end{array}$ & $\begin{array}{c}\text { S } \\
\text { D }\end{array}$ & $\begin{array}{c}\text { M } \\
\text { ea }\end{array}$ & $\begin{array}{c}\text { S } \\
\text { D }\end{array}$ & $\begin{array}{c}\text { M } \\
\text { ea }\end{array}$ & $\begin{array}{c}\text { S } \\
\text { D }\end{array}$ & \\
& & & n & & n & & \\
\hline 1 & 26 & 58 & 92 & 58 & 89 & 41 & 9 \\
& 0,9 &, 5 &, 2 &, 3 &, 1 &, 8 & \\
& 5 & 7 & 6 & 5 & 6 & 3 & \\
\hline 2 & 23 & 53 & 42 & 23 & 59 & 17 & 9 \\
& 4,3 &, 6 &, 1 &, 1 &, 2 &, 8 & \\
& 5 & 1 & 4 & 9 & 2 & 1 & \\
\hline 3 & 27 & 28 & 53 & 24 & 96 & 25 & 9 \\
& 1,7 &, 0 &, 7 &, 1 &, 1 &, 3 & \\
& 6 & 6 & 0 & 0 & 2 & 6 & \\
\hline
\end{tabular}

\section{Keterangan :}

Kelompok 1 : sebagai kontrol, tidak diaplikasikan bahan apapun

Kelompok 2 : sampel enamel yang telah disiapkan diaplikasikan selapis tipis fluoride varnish 
Kelompok 3 : sampel enamel yang telah disiapkan diaplikasikan krim CPP-ACPF HVN IE : Nilai kekerasan permukaan enamel awal (Initial Enamel)

HVN DE : Nilai kekerasan permukaan enamel setelah demineralisasi (Demineralisasi Enamel)

HVN TE : Nilai kekerasan permukaan enamel setelah melewati fase $\mathrm{pH}$ cycling (Treated Enamel)

Mean : rerata

SD : standar deviasi

$\mathrm{n}$ : jumlah sampel

HVN : Hardness Vickers Number

Dari tabel diatas dapat dilihat
pada kelompok kontrol terjadi penurunan rerata nilai kekerasan permukaan enamel dari 260,95 menjadi 92,26 setelah dilakukan demineralisasi dan terjadi penurunan lagi dari 92,26 menjadi 89,16 setelah melewati fase $\mathrm{pH}$ cycling. Pada hasil rerata kelompok fluoride varnish terjadi penurunan nilai kekerasan permukaan enamel dari 234,35 menjadi 42,14 setelah dilakukan demineralisasi dan terjadi kenaikan nilai kekerasan permukaan enamel dari 42,14 menjadi 59,22 setelah melewati fase $\mathrm{pH}$ cycling. Pada hasi rerata kelompok CPP-ACPF terjadi penurunan nilai kekerasan permukaan enamel dari 271,76 menjadi 53,70 setelah dilakukan demineralisasi dan terjadi peningkatan nilai kekerasan permukaan enamel dari 53,70 menjadi 96,12 setelah melewati fase $\mathrm{pH}$ cycling.

Pada penelitian ini nilai kekerasan permukaan enamel semua sampel sebelum perlakuan (HVN IE), setelah demineralisasi (HVN DE) dan setelah melewati fase $\mathrm{pH}$ cycling selama 14 hari (HVN TE) dimasukkan dalam rumus untuk mendapatkan presentase pemulihan kekerasan permukaan enamel (recovery). Hasil rerata presentase pemulihan kekerasan permukaan enamel pada masing- masing sampel ditampilkan pada tabel 2.

Tabel 2. Hasil Rerata Dan Standar Deviasi

Presentase Pemulihan Kekerasan Permukaan Enamel (\%)

\begin{tabular}{|c|c|c|c|}
\hline Kelompok & Mean & SD & $\mathrm{n}$ \\
\hline 1 & -9.44 & 22.69 & 9 \\
\hline 2 & 11 & 3.20 & 9 \\
\hline 3 & 31.44 & 7.25 & 9 \\
\hline
\end{tabular}

Keterangan :

Kelompok 1 : sebagai kontrol, tidak diaplikasikan bahan apapun

Kelompok 2 : sampel enamel yang telah disiapkan diaplikasikan selapis tipis fluoride varnish

Kelompok 3 : sampel enamel yang telah disiapkan diaplikasikan krim CPP-ACPF

Pada tabel 2. didapatkan hasil rerata presentase pemulihan kekerasan permukaan enamel pada kelompok kontrol yaitu $-9,44 \%$ yang menandakan tidak terjadi pemulihan kekerasan permukaan enamel (terjadi penurunan setelah melewati fase $\mathrm{pH}$ cycling). Hasil rerata presentase pemulihan kekerasan permukaan enamel pada kelompok CPP-ACPF lebih tinggi yaitu $31,44 \%$ dibandingkan dengan kelompok fluoride varnish yaitu $11 \%$.

\section{Analisa Statistik Data Hasil Penelitian Uji Normalitas dan Homogenitas}

Sebelum dilakukan uji analisis antar kelompok penelitian maka dilakukan uji normalitas terlebih dahulu pada masing-masing kelompok. Uji normalitas pada penelitian ini menggunakan uji KolmogorovSmirnov, dilakukan pula uji homogenitas varians pada keseluruhan kelompok dengan Levene test. Hasil uji normalitas Kolmogorof Smirnof menunjukkan bahwa data yang didapat pada keseluruhan kelompok berdistribusi normal ( $>>0,05)$. Uji homogenitas yang diukur dengan levene test dengan tingkat kemaknaan 
sebesar 0,05, maka data semua kelompok tidak homogen $(\mathrm{p}>0,05)$.

\section{Hasil Uji Kruskal-Wallis dan Post Hoc Tukey HSD}

Tabel 3. Hasil Uji Tukey HSD Ketiga Kelompok Perlakuan

\begin{tabular}{|c|c|c|c|}
\hline Kelompok & 1 & 2 & 3 \\
\hline 1 & - & 0.012 & 0.000 \\
\hline 2 & 0.012 & - & 0.012 \\
\hline 3 & 0.000 & 0.012 & - \\
\hline \multicolumn{4}{|c|}{$\mathrm{P}<0.05$} \\
\hline
\end{tabular}

\section{Keterangan :}

Kelompok 1 : sebagai kontrol, tidak diaplikasikan bahan apapun

Kelompok 2 : sampel enamel yang telah disiapkan diaplikasikan selapis tipis fluoride varnish

Kelompok 3 : sampel enamel yang telah disiapkan diaplikasikan krim CPP-ACPF

Hasil uji antar kelompok menggunakan Kruskal-Wallis dan Tukey HSD test. Uji Kruskal-Wallis didapatkan hasil bahwa presentase pemulihan kekerasan permukaan enamel antara kelompok kontrol, fluoride varnish dan CPP-ACPF terdapat perbedaan bermakna $(\mathrm{P}<0.05)$. Uji Tukey HSD pada tabel 3. didapatkan hasil bahwa presentase pemulihan kekerasan permukaan enamel antara kelompok kontrol dengan fluoride varnish, antara kelompok kontrol dengan CPP-ACPF dan antara kelompok fluoride varnish dengan CPP-ACPF terdapat perbedaan yang bermakna $(\mathrm{P}<0.05)$.

\section{DISKUSI}

Enamel merupakan jaringan terluar gigi yang menutupi anatomis mahkota gigi dan memiliki ketebalan yang berbeda pada setiap area gigi. Kandungan mineral yang tinggi membuat enamel mempunyai sifat yang keras, Kekerasan permukaan luar gigi berbeda-beda tergantung pada lokasinya, dan kekerasannya akan berkurang menuju ke arah dalam. ${ }^{5}$ Asam organik dihasilkan dari metabolisme bakteri dalam rongga mulut. Asam ini berdifusi melewati pelikel sampai ke permukaan enamel. Asam merusak Kristal apatit terutama di kisi yang rentan dan terdapat ion karbonat. Hal ini menyebabkan ion $\mathrm{Ca}^{2+}, \mathrm{OH}^{-}, \mathrm{PO}_{4}{ }^{2-}, \mathrm{F}^{-}, \mathrm{CO}_{3}{ }^{-}, \mathrm{Na}^{+}$dan $\mathrm{Mg}^{2+}$ keluar dari kisi kristal dan berdifusi menjadi cairan diantara kristal-kristal. Kalsium dan ion fosfat yang larut membentuk berbagai garam kalsium fosfat yang menyebar ke bagian luar atau memfasilitasi perbaikan kristal yang rusak di bawah permukaan enamel sehingga terjadi remineralisasi. Kehilangan mineral atau demineralisasi akan terjadi selama asam masih ada. Semakin banyak enamel yang larut maka semakin tinggi konsentrasi dari ion $\mathrm{Ca}$ dan $\mathrm{PO}_{4}$. Karena ion kalsium dan fosfat berdifusi keluar, remineralisasi pada permukaan menjadi lebih mungkin terjadi. Hal ini menyebabkan pembentukan surface intact layer sekitar 20-40 mikron yang kandungan mineralnya lebih tinggi dari lesi itu sendiri. ${ }^{1}$

Secara klinis lesi awal enamel tampak putih karena translusensi dari enamel telah hilang. Permukaan menjadi rapuh dan mudah dirusak. Ciri yang paling penting dari lesi white spot adalah adanya intact surface layer di atas permukaan gigi yang terdemineralisasi (40-70\%). Walaupun lesi awal enamel memiliki intact surface namun kandungan mineralnya lebih rendah dibandingkan enamel yang sehat yang berarti nilai kekerasanya lebih rendah dibandingkan dengan enamel yang sehat. $^{1}$

Dalam penelitian ini dilakukan terdapat 3 kelompok dengan masingmasing kelompok terdiri dari 9 sampel dan tiap sampelnya dilakukan tiga kali 
pengukuran kekerasan permukaan enamel. Pengukuran pertama dilakukan pada awal dengan tujuan mengetahui nilai kekerasan masingmasing sampel sebelum diberi perlakuan. Setelah dilakukan pengukuran pertama (initial enamel), sampel memasuki fase demineralisasi. Semua sampel dari ketiga kelompok direndam dalam larutan demineralisasi selama 72 jam pada suhu $37^{\circ}$ C. Hasil pengukuran sampel yang direndam dalam larutan demineralisasi $\left(\mathrm{CaCl}_{2}\right.$, $\mathrm{NaH}_{2} \mathrm{PO}_{4}$, asam laktat dan Fluor) selama 72 jam pada suhu $37^{\circ} \mathrm{C}$ menciptakan demineralisasi subsurface sekitar 150 mikron kedalamannya dengan surface intact terbentuk pada lesi awal enamel. Konsentrasi kalsium dan fosfat, dalam larutan demineralisasi, berada di $50 \%$ dari tingkat kejenuhan, menyebabkan kelarutan hanya mencapai subsurface enamel. Penambahan fluor mencegah demineralisasi dengan membentuk fluorapatit di permukaan, yang membuat lesi awal enamel memiliki surface intact layer alami. ${ }^{1}$ Fase yang terakhir adalah fase remineralisasi. Pada fase remineralisasi ini dilakukan $\mathrm{pH}$ cycling selama 14 hari. $\mathrm{pH}$ cycling yang dilakukan pada sampel dalam penelitian ini meliputi tiga jam demineralisasi menggunakan larutan demineralisasi dan sisanya 21 jam sampel direndam dalam saliva buatan. Demineralisasi dilakukan selama 3 jam setiap hari untuk mensimulasikan durasi terjadinya demineralisasi dalam rongga mulut (low cariogenic challenge). Setiap harinya dilakukan aplikasi bahan fluoride varnish pada kelompok 2 dan CPP-ACPF pada kelompok 3 dua kali sehari sesuai rekomendasi penggunaan profilaksis oral sehari-hari.

Dari nilai kekerasan permukaan enamel (HVN) menggunakan alat Vickers Microhardness Tester diperoleh hasil pada kelompok 3 yaitu sampel enamel yang diaplikasikan CPP-ACPF memiliki rata-rata peningkatan nilai kekerasan permukaan enamel yang tertinggi dibandingkan dengan kelompok 1 (kontrol) dan kelompok 2 yaitu sampel enamel yang diaplikasikan fluoride varnish.

Data hasil statistik pada kelompok kontrol didapatkan penurunan yang signifikan dari nilai kekerasan enamel awal ke nilai kekerasan enamel setelah demineralisasi dan terjadi penurunan dari nilai kekerasan enamel setelah demineralisasi ke nilai kekerasan enamel setelah melewati fase $\mathrm{pH}$ cycling namun tidak signifikan. Pada hasil statistik kelompok fluoride varnish didapatkan penurunan yang signifikan dari nilai kekerasan enamel awal ke nilai kekerasan enamel setelah demineralisasi dan terjadi peningkatan dari nilai kekerasan enamel setelah demineralisasi ke nilai kekerasan enamel setelah melewati fase $\mathrm{pH}$ cycling namun tidak signifikan. Pada hasil statistik kelompok CPP-ACPF didapatkan penurunan yang signifikan dari nilai kekerasan enamel awal ke nilai kekerasan enamel setelah demineralisasi dan terjadi peningkatan dari nilai kekerasan enamel setelah demineralisasi ke nilai kekerasan enamel setelah melewati fase $\mathrm{pH}$ cycling yang signifikan juga. Berdasarkan data-data tersebut dapat disimpulkan bahwa hasil peningkatan nilai kekerasan permukaan enamel yang paling baik adalah kelompok CPP-ACPF diikuti dengan kelompok fluoride varnish dan yang terakhir kelompok kontrol.

Presentase pemulihan kekerasan permukaan enamel telah dihitung pada semua sampel dari 3 kelompok. Hasilnya menunjukkan pemulihan yang paling baik adalah kelompok CPP-ACPF $(31,44 \%)$ diikuti dengan kelompok fluoride varnish 
(11\%) dan yang terakhir kelompok kontrol $(-9,44 \%)$ yang tidak mengalami peningkatan nilai kekerasan permukaan enamel. Analisis data statistik yang membandingkan ketiga kelompok tersebut menyatakan bahwa terdapat berbedaan yang signifikan antara kelompok kontrol dengan kelompok fluoride varnish, antara kelompok kontrol dengan kelompok CPP-ACPF dan antara kelompok fluoride varnish dengan kelompok CPP-ACPF. CPP-ACPF terbukti lebih baik dalam meningkatkan remineralisasi dilihat dari nilai kekerasan pemukaan enamel daripada fluoride varnish. Hal ini dapat terjadi kemungkinan karena kandungan fluor pada CPP-ACPF (0,2\%) lebih besar dibandingkan pada fluoride varnish $(0,1 \%)$. Fluor yang diasorbsi oleh enamel akan membentuk fluorapatit. Fluorapatit ini lebih tidak mudah larut dibandingkan dengan hidroksiapatit. $^{6} \quad$ Selain itu remineralisasi membutuhkan kalsium dan fosfat yang biasanya terkandung dalam saliva. Remineralisasi dapat ditingkatkan dengan adanya fluor. Fluor selain dapat meningkatkan remineralisasi dapat juga menghambat demineralisasi dan menghambat bakteri plak. ${ }^{7}$ Pada CPP-ACPF teerkandung ion kalsium, fosfat dan juga fluor sehingga proses peningkatan remineralisasi lebih tinggi daripada fluoride varnish yang hanya mengandung fluor saja. Fluor sendiri tidak dapat meningkatkan remineralisasi jika tidak terdapat ion kalsium dan fosfat. Pada fluoride varnish kalsium dan fosfat hanya didapatkan dari saliva buatan.

Saat $\mathrm{pH}$ turun tidak lebih rendah dari 4,5 dan terdapat fluor pada cairan biofilm, hydroxyapatite (HA) larut dan pada saat yang bersamaan fluorapatite (FA) terbentuk. Hasil akhirnya adalah penurunan pelarutan enamel, karena kalsium dan fosfat yang larut dari HA diperoleh kembali dalam enamel dengan bentuk FA. ${ }^{8}$ Cara yang jelas untuk meningkatkan remineralisasi dan untuk membuatnya lebih efektif adalah menyediakan kalsium dan fosfat, terutama ketika aliran air liur tidak memadai dan mebuat fluor lebih efektif dengan jangka waktu yang lebih lama. ${ }^{7}$

Pada penelitian ini standart deviasi dari masing-masing kelompok cukup besar dan terdapat kelompok yang tidak homogen. Hal tersebut terjadi karena menurut Fejerskov dan Kidd sebagian besar kristal enamel tidak homogen. ${ }^{6}$ Kandungan bahan anorganik pada enamel pun semakin kedalam semakin sedikit karena itu kekerasan permukaan enamel semakin kedalam akan semakin berkurang.

\section{SIMPULAN}

Dari hasil penelitian ini dapat dibuktikan bahwa kekerasan permukaan enamel setelah aplikasi bahan CPP-ACPF lebih tinggi dibandingkan dengan bahan fluoride varnish.

\section{DAFTAR PUSTAKA}

1. Lata S., Varghese N.O., Varughese J.M. 2010. Remineralization Potential of Fluoride and Amorphous Calcium Phosphate on Enamel Lesions: An in Vitro Comparative Evaluation. $J$ Conserv Dent. vol 13 (1). pp. 42-46

2. Dogan F., Civelek A., Oktay I. 2004. Effect of Different Fluoride Concentration on Remineralization of Remineralized Enamel. Istanbul, Turkey. OHDMBSC. Vol.3 (1).pp. 20-26

3. Agnihotri Y., Namratha L.P., Patri G., Thajuraj P.K. 2012. 
The Effecof CPP-ACP on Remineralization of Artificial Caries like Lesions: An in Vitro Study. Indian Journal of Multidiciplinary Dentistry. Vol2(1).pp. 366-369

4. ElSayad I., Sakr A., Badr Y. 2009. Combining casein phosphopeptide-amorphous calcium phosphate with fluoride: synergistic remineralization potential of artificially demineralized enamel or not?. Journal of Biomedical Optics 144.

5. Sluder T.B. 2001. Clinical dental anatomy, histology, physiology and occlusion. Sturdevant C.M., Barton R.E., Sockwell C.L., Strickland W.D. The Art and science of Operative ] IDentistry. New Delhi : Mosby. pp: 7-18

6. Fejerskov O. dan Kidd E. 2008. Dental Caries : The Desease and Its Clinical Management. $2^{\text {nd }}$ edition. pp. 214

7. Featherson JDB. 2009. Remineralization, the Natural Caries Repair Process - The Need for New Approaches. Adv Dent Res. 21: 4-7

8. Cury J.A. and Tenuta L.M.A. 2009. Enamel Remineralization: Controlling The Caries Disease or Treating Early Caries Lesions?. Braz. Oral Res. 23(1). pp. 23-30

9. Aimutis, William R. 2004. Bioactive properties of milk proteins with particuar focus on anticariogenesis. J Nutr.pp. 989-995

10. Angela, A. 2005. Pencegahan Primer Pada Anak Yang Berisiko Karies Tinggi. Maj. Ked. Gigi. (Dent. J.), Vol. 38. No. 3

11. Agnihotri Y., Namratha L.P., Patri G., Thajuraj P.K. 2012.
The Effecof CPP-ACP on Remineralization of Artificial Caries like Lesions: An in Vitro Study. Indian Journal of Multidiciplinary Dentistry. Vol2(1).pp. 366-369

12. Marya CM. 2007. Fluoride Varnish : A Useful Dental Public Health Tool. The Internet Journal of Dental Science 4: 1-5

13. Murray JJ., Gun Rugg JA, Jenkis NG. 1991. Fluoride In Caries Preventions. Britain : Butterworth LTD. pp: 130; 187

14. Narayanan L. Laskmi. 2010. Essentials of Operative Dentistry. India : Jaypee Brothers Medical Publishers. pp : 4-8

15. Oshiro M., Yamaguchi K., Takamizawa T., Inage H., Watanabe T., Irokawa A. 2007. Effect of CPP-ACP paste on tooth mineralization : an FEM - SEM study. $J$ of Oral Science. 2(49). pp. 115-120

16. Reyes-Gasga J, GutierrezSalazar MP. 2003. Microhardness and chemical composition of human tooth. Mat. Res 6: 1-10.

17. Reynolds EC. 2006. Casein phosphopeptide - amorphous calcium phospate and the remineralization of enamel. US Dentistry . pp: 51-4.

18. Santhosh BP, Jethmalani P, Shashibhushan KK, Subba Reddy VV. 2012. Effect of phosphate containing chewing gum on salivary concentration of calcium and phosphorus : An in vivo study. J Indian Soc Pedod Prev Dent., Apr - Jun 2012;(30)2.pp. 146-150 